\title{
The Roles of Determinants of Self-employment: A Mediation of Entrepreneurial Motivation in Bauchi State, Nigeria
}

\author{
Muhammad Adamu ${ }^{1,2}$ \\ Mahani Bint Mohammad Abdu Shakur ${ }^{1}$ \\ ${ }^{1}$ Department of Business Management, Faculty of Economics and Business, Universiti Malaysia Sarawak, \\ Malaysia \\ ${ }^{2}$ Department of Business Administration, Faculty of Social and Management Sciences, Bauchi State University \\ Nigeria \\ Correspondence: Muhammad Adamu, Department of Business Administration, Faculty of Social and \\ Management Sciences, Bauchi State University, Nigeria, Email: majalamm@gmail.com
}

Received: November 06, $2017 \quad$ Accepted: November 11, $2017 \quad$ Online Published: November 17, 2017

\begin{abstract}
Today, the problem of unemployment has been a global issue, even among the developed nations, and especially the developing nations. For this reason, the need for employment generation becomes desirably indispensable. The aim of this research work is to examine the essential roles that entrepreneurial traits and economic incentive factors would play with the mediation of entrepreneurial motivation for an effective self-employment start-up accomplishment. Self-employment has long been recognized as an alternative for individuals to become self-reliant. Thus, this is expected brings about a reduction in poverty level, improved living standard as well as to earn more income and have a better career as a means of sustenance for potential entrepreneurs. For this purpose, it is essentially important to make an examination of certain vital factors, which may constitute the basics necessary to effect self-employment particularly from the context of entrepreneurial traits and economic incentive factors that would motivate the potential entrepreneurs to achieve success in self-employment start-up.
\end{abstract}

Keywords: Entrepreneurial Motivation, Entrepreneurial Traits, Economic Incentives, Potential Entrepreneurs, Self-Employment.

\section{Introduction}

Recently, the global financial crisis has caused a lot of setback due the economic downturn among nations. Many organizations are cutting their work force size, and at the same time were very reluctant to create jobs and employ other unemployed individuals (Fritsch \& Wyrwich, 2017).Thus, this added more disadvantages to the potential entrepreneurs in their vulnerable situations that trailed their condition as job seekers. For this reason, this study would make an investigation into the impact of entrepreneurial traits and economic incentive factors through the mediation of entrepreneurial motivation to measure self-employment. The emergence of interest in self-employment is evident, as it is receiving more attention from researchers all over the world (van Stel et al., 
The Roles of Determinants of Self-employment: A Mediation of Entrepreneurial Motivation in Bauchi State, Nigeria

2017; Livanos, 2009). Self-employment is considered to be important and positively associated with wealth creation, improvement in living standard as well as an overall expected reduction in poverty level (Huelva, 2009). The self-employment has been in practice across the globe. It was initially trade by barter which is the exchange of goods for goods or services was solely the practice, but with global economic evolution, the commodity money was started due to the trends within the discipline. As a result of this consequence, trade by barter transaction was replaced by the use of tangible money or cash, which brings new insight into self-employment development (Nicks, 2008). This process brings about specialization among producers due to the later transformation of the system into a trade of goods and services, while the communities came to realize the areas of production that they are best specialized and put more attention and concentration on it.

The consequence of this development brings about the self-employment practice (Nicks, 2008; Raimi \& Adeleke, 2010). This self-employment practice resulted in the establishment of entrepreneurship development programmes that are mainly skills acquisition in nature as part of any government's intervention and effort to encourage unemployed potential entrepreneurs to be self-employed by owning and managing a business (Ezekiel \& Edwin, 2016). The entrepreneurship development programmes were seen as an economic tie mainly through support and motivation to have a favourable and conducive atmosphere for entrepreneurship development. According to Cahna (2008), with the government policy intervention on entrepreneurship, economic opportunities meant for potential entrepreneurs would be a meaningful support to attain an achievable reality of self-employment among nations.

\section{Literature Review \\ 2.1 Self-employment}

The concept of self-employment has been regarded as an important source and a way in which entrepreneurial abilities of individuals are employed, as well as the creation of new jobs within the society in countries where large and increasing unemployment has become a major economic problem. This reversing trend has been stressed attracting the attention of several stakeholders and entrepreneurship practitioners in trying to identify the main determinants of self-employment (Oppong et al., 2015). Evans et al. (2009) argued that as a contribution towards self-employment, a utility-maximizing career choice made by an individual can be modelled from the context of the decision to be an entrepreneur. Potential entrepreneurs when they start their own businesses would then be a source of employment opportunities for others, as they may not hesitate to employ other individuals to work for them, and this expands self-employment and generates more jobs (Fátima, 2012). The larger number of self-employed will increase efficiency and competition, and taken together, will increase the real incomes in a society. Most governments apparently believe that higher levels of enterprising behaviour among the entrepreneurs results in job creation and may likely promote economic growth (Oppong et al., 2015).

Self-employment presents an opportunity as a way to answer to nobody and to set their own schedule, to become rich and to work based on a personal schedule (Evans et al., 2009). It is seen by the governments on the other hand, as a means to offer aid and assistance for entrepreneurs to attain this objective and frequently as a route to end poverty. Increased self-reliance and well-being through creation of new firms may also raise the degree of competition in the product market, bringing gains to consumers, thus create new jobs. The justification for these actions is usually recognized that self-employment will help to promote innovation and invention through effective self-employment practice (Huelva, 2009; Livanos, 2009).

\subsection{Entrepreneurial Motivation}


The Roles of Determinants of Self-employment: A Mediation of Entrepreneurial Motivation in Bauchi State, Nigeria

The entrepreneurial motivation refers to the support that is expected to be given to a potential entrepreneur in order to energize him to make much effort to attain self-employment. In this direction, it is important to focus on the closest stage during the potential entrepreneur's decision to become self-employed. Since having the intention to be involved in entrepreneurial activity do not automatically induce entrepreneurial behaviours (de Jong, 2013), it is essential to understand what triggers the decision of potential entrepreneurs to accomplish what they intend to accomplish self-employment. Thus, providing them with appropriate entrepreneurial motivations may give them more courage in achieving self-employment (Braunerhjelm et al., 2010).

Previous empirical research on the role of motivation of entrepreneurs has been strongly affirmed by several authors (Lee, Wong, Foo \& Leung, 2011). Scholars such as (Yushuai et al., 2014; Kisker, 2016; Isa \& Muhammad, 2015; Awruk \& Staniewski, 2015) who looked critically on the role of motivation of entrepreneurs in their empirical research emphasized the importance of motivation of entrepreneurs for the self-employment attainment. The authors define business creation as the identification of business opportunities and access to appropriate resources for entrepreneurs. Dozen and O'Neill, (2017) emphasize that the lack of or limited empirical research on the motivation of entrepreneurs is not an indication of the lack of relevance of entrepreneurial motivation as a research area. Shane et al. (2012) invoked for the influence of human motivation in the process of self-employment/business creation on developing a more realistic explanation of entrepreneurial motivation. They consider the explanations of the recent literatures as inadequate. The motivation of entrepreneurs is an important research field to explain the development of new ventures based in the field of entrepreneurship (Yushuai et al., 2014; Kisker, 2016).

\subsection{Entrepreneurial Traits}

Proactively, taking a decision to become self-employed which has become the focal point in the investigation of entrepreneurship regarding individual's qualities as an entrepreneur is a very important decision to an individual. Due to the multi-dimensionality of entrepreneurial traits, many pieces of research have been conducted on the entrepreneur's traits and its relations to being a determinant of self-employment. However, despite this multidimensionality of the entrepreneurial characteristics, this research will further concentrate and investigate three dimensions of the entrepreneurial traits that were overlooked and not been over-researched, such as transformationality, resilience, and autonomy (Mukherjee, 2010). Also, according to Renko et al. (2012) although these traits were identified from the literature, they were usually overlooked in measuring self-employment.

Transformationality is seen as an essential trait of an entrepreneur through which they enhance the morale, motivation, as well as inspires changes driven, mobilizes resources and challenge status-quo in self-employment (Georgianna, Müller, Schermelleh-Engel and Petersen, 2016). Transformational entrepreneur is less tenacious in his beliefs and open to experiences. Interaction with the business world leads to self-doubt and problems surface, thereby challenging the status-quo and rise for a change. In their empirical findings, Leonelli and Masciarelli (2017) maintained that potential entrepreneurs with transformational traits are much motivated to practice entrepreneurship most particularly, the start-up stage. This indicates that, transformationality trait may play a very vital role for entrepreneurs most especially, at the starting point, which is essentially significant among all entrepreneurs. Also, Ling et al. (2008) affirmed that entrepreneurs with such trait are capable of harnessing and utilizing overall resources to achieve targets in self-employment. The scholars also found that, such entrepreneurs with transformational traits have the courage to challenge a status quo. Thus, it is important to bring in new ideas that may result in 
The Roles of Determinants of Self-employment: A Mediation of Entrepreneurial Motivation in Bauchi State, Nigeria

Muhammad Adamu andMahani Bint Mohammad Abdu Shakur

positive steps forward in self-employment context. The need for autonomy/control among entrepreneurs is also essential.

According to Aziz et al. (2013), the need for autonomy involves independent self-determination, the process by which entrepreneurs control the way they carry out their own business rather than taking directives from others. The need for autonomy is a prime driver of entrepreneurship (Caliendo, Fossen, \& Kritikos, 2012). Autonomy is important for entrepreneurs because it enables them to have control over their environment, set their own goals, incorporate elements of innovation, make their own decisions independent of external managerial control, and essentially regulate their own behaviour (Rauch \& Frese, 2007). Autonomy leads to well-being and this would explain why autonomy in the entrepreneurial environment might be a compensator for higher income in a less autonomous position (Renko et al. 2012). Work that provides autonomy is more intrinsically motivating than work that does not. Research relating to entrepreneurial motivation shows autonomy, to be the most often mentioned, or most importantly rated motive to start a business (Akehurst et al. 2012). Empirical support for the concept is found in Rauch and Frese (2007) meta-analysis of the relationship between autonomy and business success. Another important entrepreneurial trait is resilience.

Hayward et al. (2010) affirmed that the ability to bounce back from entrepreneurial failure has been a cornerstone where resilience is understood. Most entrepreneurs will have experienced venture failure and therefore the ability to bounce back is seen as a crucial self-motivation in new venture formation. Hayward et al. (2010) emphasized that resilience informs confidence, and confidence facilitate the capacity of the individual to broaden and build their thought. This results in access to additional or improved resources for their ventures, and facilitate their likelihood of forming subsequent ventures (Morris et al. 2008). The uncertainty, ambiguity or novelty inherent in the self-employment process is coupled with the emotionally intense experiences tending to generate a less flexible and schema-driven behaviour in the face of changing unscripted environments. Blatt (2009) acknowledged that resilience is an important quality for entrepreneurs, especially in new business start-up.

\subsection{Economic Incentive Factors}

Recently, interest in self-employment has increased, as well as for enhancing the environment for new ventures is growing (Chowdhury, 2017). An economic incentive is seen as support and assistance provided as a basis to start or retain business operations (Idris, 2015). In practice, however, it is a broadly used term denoting an array of reimbursement designed to promote new business activity or to encourage business or job creation. These benefits principally encompass tax and financing incentives, infrastructure, ICT facilities, as well as skills acquisition provided by governmental and non-governmental bodies. In the literature, the influence of a variety of different factors has been evaluated on the success of self-employment. Due to the large number of different factors, it can be assumed that each factor will have a relative impact on the self-employment start-up among potential entrepreneurs (Mercy, 2016).

In the investigation of incentives for achieving self-employment, it is therefore expected that any significant influence by the variety of different factors will be of significant importance for the potential entrepreneurs. Mandl and Curtarelli (2017) maintained that the links between ICTs availability and access and its unwavering importance of enhancing self-employment among the entrepreneurs have been the subject of so much attention and concern. Emerging and developing economies are seeking ways to improve productivity and find new sources of growth through new technologies vested through self-employment. Silva and Ratnadiwakara (2010) in their investigations revealed that on the developed countries, technological progress from the context of ICT 
The Roles of Determinants of Self-employment: A Mediation of Entrepreneurial Motivation in Bauchi State, Nigeria

continues at a relentless speed.

Kerr et al. (2011) and Nagpal et al. (2009) maintained and emphasized that most governments financing effort toward providing incentives for self-employment should be intensified. This indicates that financing is a vital element in effecting and realizing a successful self-employment. The researchers also identified that approach to financing is the most important incentive to be made available for individuals who have the motive of achieving self-employment. Moreover, according to Dike (2013), Elebute and Shagaya (2016), a reasonable percent of the entrepreneurs should have training such as of vocational training, which may enable them to practicing varieties of occupations involving such utilization of the vocational training in achieving their self-employment target. Furthermore, according to Feyitimi et al. (2016), taxation incentives may exert an indispensable role in motivating the potential entrepreneurs in attaining self-employment. Also, the essences of machinery/equipment have been considered by Melia, Perez \& Dobon (2010). The scholars observed that due cognizance should be given to machinery/equipment based on the variety of occupations that the potential entrepreneurs may chose to engage in achieving self-employment.

\section{Research Gaps and Contributions}

From the theoretical point of view, there has been an increased focus to establish a relationship between determinant factors of self-employment (Bryan, 2013; Johannsen, 2012; Noella et al., 2015; Cooney, 2012; Mallya, 2011). However, there are also studies where such a relationship has not been found (Szirmai et al., 2011; Kerr et al., 2011; Gill et al., 2011; Ramoni, 2016). Due to theses inconsistencies, the recent economic downturn and incessant trends in technology, uncertainties and anxiousness surrounds the potential entrepreneur's self-employment start-up. Consequently, at this point, although some entrepreneurial traits were upheld by several scholars as basic determinants of self-employment, but potential entrepreneurs must be supported with any other incentives such as economic incentives to make the self-employment ambition a reality. A number of scholars (Coon, 2004; Simpeh, 2011; Romani, 2016; Koomson, 2015; Mukherjee, 2010) extensively use the personality trait theory to measure and consider self employment. This self-employment concept is measured in terms of the traits associated with entrepreneurs. However, from the economic point of view, a good number of scholars (Papanek \& Harris, 1972; Kumar et al., 2011; Saleemi, 2009; Kiragu \& Sakwa, 2013; Mokua \& Memba, 2015) measured self-employment or job creation using economic entrepreneurship theory in terms of some selected economic incentive factors as a predictor of self-employment. This shows that self-employment is being measured and practiced from both the psychological and economic domains. Thus, this brings about a practice in an overlapping position. According to Dissanayake (2013) and Uyangoda (2011), whenever two theories were used to establish relationships between variables to measure a certain concept of the different context of domain, such theories can be amalgamated together as a theory extension, to have a clearer appreciation of the concept. This demonstrates how the theoretical extension is executed with the objective of producing new knowledge by incorporating two subject domains (Dissanayake, 2015). Therefore, this present study amalgamated the personality trait theory and economic entrepreneurship theory together in order to fill the theoretical research gap and eliminate the applicability and practical problems faced by the potential entrepreneurs. The depicted framework below (Figure 1) shows the relationship between entrepreneurial traits that is measured by transformationality, resilience, and autonomy, economic incentive factors are measured by ICTs, vocational training, taxation incentives, financing, and machinery/equipment, and the mediation of entrepreneurial motivation in effecting self-employment. 


\section{Entrepreneurial Traits}

\begin{tabular}{|l|}
\hline Transformationality \\
\hline Resilience \\
\hline Autonomy \\
\hline Economic Incentives \\
\hline ICT (Facility) \\
\hline Vocational Training \\
\hline Taxation Incentives \\
\hline Financing \\
\hline Machinery/Equipment \\
\hline
\end{tabular}

Figure 1: Conceptual Framework

\section{Conclusion}

The economic entrepreneurship theory, the personality traits theory, and Gallup entrepreneurship model have been prominent in measuring self-employment. With consideration to this model, self-employment is measured and dependent on two major variables with their eight constructs through entrepreneurial motivation. The variable of entrepreneurial traits such as transformationality that concentrates on effective harnessing of resources and revolting to a status quo that may require change by potential entrepreneurs. The resilience trait relates to the potential entrepreneur's capacity to bounce back after, or in case of adversity that may occur in attaining to self-employment. Autonomy also resides the potential entrepreneurs of ability of being independent with less control to make effective decisions in self employment. The economic incentive variable would measure self-employment through ICTs, vocational training, taxation incentives, financing, and machinery/equipment. Thus, theses would give the potential entrepreneur ability to harness and mobilizes resources to become effectively and efficiently self-employed.

\section{Limitation of the Study and Area for Further Studies}

This study focused in assessing self-employment outcome from the new business start-up perspectives. However, the current study has not outlined and examined the effect of the constructs entrepreneurial traits and economic incentive factors on other dimensions of self-employment measures such as business sustainability and business performance (Jeremy et al., 2010; William et al., 2006; Taiyuan et al., 2017). These might have limited the contribution of this study. Future research should incorporate those 
The Roles of Determinants of Self-employment: A Mediation of Entrepreneurial Motivation in Bauchi State, Nigeria

dimensions of self-employment outcomes in their models.

Secondly, the present study is limited as it only considered the effect of entrepreneurial motivation as a mediator. On this note, suggestions for moderating and mediating the constructs of entrepreneurial traits and economic incentive factors relationships have been provided. Future researchers can examine the possibility of using other essential variables such entrepreneurial self-efficacy and self confidence in relation to self-employment as a moderating or mediating variable between entrepreneurial traits and economic incentive factors in attaining self-employment (Frese et al., 2011).

References

Akehurst, G., Simarro, E. \& Mas-Tur, A., (2012) Women Entrepreneurship In Small Service Firms: Motivations, Barriers And Performance. The Service Industries Journal, 32(15), pp.2489-2505.

Aziz, N., Friedman, B. A., Bopieva, A., and Keles, I. (2013). Entrepreneurial Motives and Perceived Problems: An Empirical Study of Entrepreneurs in Kyrgyzstan. International Journal of Business Research, 18(2).

Blatt, R. (2009) 'Resilience in Entrepreneurial Teams: Developing the Capacity to Pull Through', Frontiers of Entrepreneurship Research, vol. 29, no. 11, pp. 1-14.

Braunerhjelm, P., Z. Acs, D. Audretsch, and B. Carlsson (2010). The Missing Link: Knowledge Dilusion And Entrepreneurship In Endogenous Growth. Small Business Economics 34 (2), $105\{125$

Bryan J. L. (2013) The Impact of Government Policy on Economic Growth Management Faculty Publications Bridgewater State University, Paper 23.

Available at: http://vc.bridgew.edu/management_fac/23

Cahna, M. (2008) Indigenous Entrepreneurship, Culture and Micro - Enterprise in the Pacific Island: a Case Study from Samoa. Journal of Entrepreneurship and Regional Development, Vol. 20, Iss.1, pp. 1- 18.

Caliendo, M., F. M. Fossen, and A. S. Kritikos (2014). "Personality characteristics and the decision to become and stay self-employed." Small Business Economics42:4 (2014): 787-814

Chowdhury, F. N. (2017) A Study Of Entrepreneurship Development In Bangladesh: Pros And Cons Dhaka, Journal of Asian Scientific Research

Cooney T. M. (2012) Entrepreneurship Skills for Growth-Orientated Businesses

Dublin Institute of Technology Report for the Workshop on 'Skills Development for SMEs and Entrepreneurship', Copenhagen

De Jong, J. P. J. (2013) 'The Decision To Exploit Opportunities For Innovation: A Study Of High-Tech Small-Business Owners', Entrepreneurship Theory and Practice, 37(2), pp. 281-301.

Dike, V. E. (2013) Technical and Vocational Education and Training (TVET): Understanding the Nigerian Experience (C) Copyright 2013All Rights Reserved

Dissanayake S.W. (2015) Research, Research Gap and the Research Problem University of Kelaniya, Sri Lanka

Dissanayake D.M.N.S.W. (2013 Research, Research Gap and the Research Problem Online at https://mpra.ub.uni-muenchen.de/47519/MPRA Paper No. 47519, UTC Sri Lanka

Elebute, A. and Shagaya, O. M. (2016) Impact Of Vocational And Technical Education On Livelihood Sustenance And Economic Development In Nigeria: The Art Workshop Experience International Journal of Vocational and Technical Education Research Vol.2, No.2, pp.15-35, Published by European Centre for Research Training and Development UK (www.eajournals.org)

Evans, D.S. and L.S. Leighton (2009), Small business formation by unemployed and employed workers, Small Business Economics 2, pp. 319-330. 
The Roles of Determinants of Self-employment: A Mediation of Entrepreneurial Motivation in Bauchi State, Nigeria

Ezekiel O. Ayoade1 and Edwin M. Agwu (2016) Employment Generation through Entrepreneurial Development: The Nigerian Experience British Journal of Economics, Management \& Trade 11(3): 1-14, , Article no.BJEMT.21740,Science domain international www.sciencedomain.org

Fátima M. J. A. (2012) On Becoming Self-Employed: Gender, Class And Entrepreneurship In Portugal 2012 School Of Social Sciences

Fritsch, M., \& Wyrwich, M. (2017). Persistence of Regional Entrepreneurship: Causes, Effects, and Directions for Future Research (No. 2017-003). Friedrich-Schiller-University Jena.

Frese, M., Gielnik, M. M. (2014) The Psychology Of Entrepreneurship. Annual Review of Organizational Psychology and Organizational Behavior, 1, 413-438.

Georgianna, S., Müller, G. F., Schermelleh-Engel, K. and Petersen, B.(2016) Entrepreneurs' Job Satisfaction and Its Relationship to SuperLeadership and Self-Leadership Vanguard University of Southern California. Journal of Research in Business, Economics and Managementwww.scitecresearch.com Volume 6, Issue 3 www.scitecresearch.com/journals/index.php/jrbem/index 928 SCITECH Volume 6, Issue 3

Gill, A., Biger, N., \& Nagpal, V. (2011). Barriers to small business creations in Canada. International Journal of Entrepreneurship and Small Business, 14(2), 245-257.

Hayward, M. LA, Forster, W. R., Sarasvathy, S. D. and Fredrickson, B. L. ( 2010) 'Beyond Hubris: How Highly Confident Entrepreneurs Rebound To Venture Again', Journal of Business Venturing, vol. 25, no. 6, pp. 569-578.

Idris A. (2015) Entrepreneurial Motivation in Nascent entrepreneurship, An assessment of business start-up in Ghana, ncsuu, JPK

Isa, Y. Z. M., Abu Bakar, Y. A., Ahmad, S. (2016) Determinant Factors Of Women Entrepreneurs' Business Performance : A Conceptual Framewok Journal of Global Business and Social Entrepreneurship (GBSE) Vol. 1: no. 1 gbse.com.my | eISSN 24621714| 55

Johannsen, B. (2013). "When are the effects of fiscal policy uncertainty large?" http ://gradstudents.wcas.northwestern.edu/-bkj463/paper.pdf.

Kerr, W. and Nanda R (2011) Financing Constraints and Entrepreneurship, in Audretsch, David, Oliver Falck, and Stephan Heblich (eds.) Handbook of Research on Innovation and Entrepreneurship, Cheltenham, U.K.: Edward Elgar Publishing, 88-103.

Kiragu E. M. and Sakwa M. (2013) Effect Of Group Lending Mechanism On Enterprise Development Of Rural Women In Kenya. A Survey Of Kenyenya District, Kisii County-Kenya Ijcrb.Webs.Com Interdisciplinary Journal Of Contemporary Research In Businesscopy Right Institute of Interdisciplinary Business Research 556VOL 4, NO 12

Kisker C. E. W. (2016) Impact Of Motivational Factors Of Nascent Entrepreneurs On Business Surviving Success Riga, 2016 Vol 23, No 1

Koomson I., Peprah J., Afoakwah C. (2015) Savings, entrepreneurial trait and self-employment: evidence from selected Ghanaian Universities

Kumar, A.S., Poornima, C.S., Abraham, K.M and Jayashree, K. (2011). Entrepreneurship Development. New Delhi: New age international Publisher.

Leonelli, S., Ceci, F., \& Masciarelli, F. (2017). The importance of entrepreneurs' traits in explaining 
The Roles of Determinants of Self-employment: A Mediation of Entrepreneurial Motivation in Bauchi State, Nigeria

start-ups' innovativeness. Sinergie Italian Journal of Management.

Ling, Y. A. N., Simsek, Z., Lubatkin, M. H., \& Veiga, J. F. (2008). Transformational leadership's role in promoting corporate entrepreneurship: Examining the CEO-TMT interface. Academy of Management journal, 51(3), 557-576.

Livanos, I. (2009), What determines self-employment? A comparative study, Applied Economics Letters 16 (3), pp. $227-232$.

Mallya L. S. (2011) Successful Entrepreneurs Of Indian Origin: A Case Study Educational And Research Institute University (Established Under Section 3 Of The Ugc Act, 1956) Chennai - 600095

Mandl, I., \& Curtarelli, M. (2017). Crowd Employment and ICT-Based Mobile Work-New Employment Forms in Europe. In Policy Implications of Virtual Work (pp. 51-79). Springer International Publishing.

Mokua, C. M. and Memba, F. (2015) Effect of Progressive Lending Mechanism on Access to Finance in Rural Kenya: A Survey of Masaba North District The International Journal Of Humanities \& Social Studies (ISSN 2321 - 9203)

Morris, M.H., Kuratko, D.F. and Covin, J.G. (2008) Corporate entrepreneurship and innovation. Mason, Ohio: Thomson South-Western.

Mukherjee, S. (2010) Profiling the Urban Women Micro-entrepreneurs in India, article in the Journal of Entrepreneurship Development

Nicks (2008). The History of Entrepreneurship in Nigeria. Retrieved from: http://bizcovering.com//history/thehistory-of-entreprenership-in-Nigeria

Noella, N. and Narcisse K. (2015) Entrepreneurial Infrastructure For The Development Of Entrepreneurs In Rwanda. Växjö, Sweden

Oppong, S. and Paul, R. S. (2015) Managing Graduate Unemployment In Emerging Economies: Critical Analysis Of The Skills Mismatch And Oversupply THESES 2 UDC / UDK: 331.56-057 JEL classifi cation / JEL klasifi kacija: J64 Review /

Papanek G. F. (1972) The Development Of Entrepreneurshp, Kilby (ed.), Entrepreneurship and Economic Development, The Free Press, Newyork

Ramoni S. A. (2016) Determinants of Entrepreneurial Intention among Nigerian University Graduates World Journal of Social Sciences Vol. 6. No. 1. Issue. Pp. 45 - 59

Raimi, L. and Adeleke, I. (2010) Using Entrepreneurship Development and Corporate Social Responsibility as Strategies for Conflict Resolution in the Niger Delta Region of Nigeria, 34th Annual SPE International Technical Conference and Exhibition in Tinapa-Calabar, Cross River State, Nigeria

Renko, M., Shrader, R. C., and Simon, M. (2012). Perception Of Entrepreneurial Opportunity: A General Framework. Management Decision, 50(7), 1233-1251.

Rauch, A., and Frese, M. (2007) Let's Put The Person Back Into Entrepreneurship Research: A meta analysis on the relationship between business owners' personality traits, business creation, and success. European Journal of Work and Organizational Psychology, 16, 353-385

Sozen, E., \& O’Neill, M. (2018). An Exploration of the Motivations Driving New Business Start-up in the United States Craft Brewing Industry. In Craft Beverages and Tourism, Volume 2 (pp. 195-212). Palgrave Macmillan, Cham.

Szirmai, E, Naudé, W and Goedhuys, M (2011) Entrepreneurship, Innovation and Economic Development, Oxford University Press, Oxford. 
The Roles of Determinants of Self-employment: A Mediation of Entrepreneurial Motivation in Bauchi State, Nigeria

\section{Muhammad Adamu andMahani Bint Mohammad Abdu Shakur}

Staniewski, M. and Awruk, K. (2015) Motivating Factors And Barriersin The Commencement Of One's Own Business For Potential Entrepreneurs, Economic ResearchEkonomska Istraživanja, DOI: 10.1080/1331677X.2015.1083876 Economic Research-Ekonomska IstraživanjaISSN: 1331-677X (Print) 1848-9664 http://www.tandfonline.com/loi/rero20 @2015

Saleemi, N. A. (2009) Entrepreneurship simplified. Nairobi: Saleemi Publication Limited

Uyangoda, J. (2011) Writing Research Proposals in the Social Sciences and Humanities: A theoretical and practical guide. Colombo: Social Scientists's Association.

Yushuai, W., Na, Y. and Changping, W. (2016) An Analysis of Factors Which Influence Entrepreneurial Motivation Focused on Entrepreneurs in Jiang Xi Province in China Journal of Applied Sciences 14 (8): 767-775, 2014 ISSN 1812-5654 / DOI: 10"3923/jas"2014.767.775 2014 Asian Network for Scientific Information Journal of Applied Sciences http:// www.scholarly-journals.com/SJBA ISSN 2276-7126

Jeremy, K. H., Gregory A. D., Michael J.L. (2010). Sustainable development and entrepreneurship: Past contributions and future directions Author links open overlay panel Journal of Business Venturing Volume 25, Issue 5, Pages 439-448

Van Stel, A., Millán, A., Millán, J. M., \& Román, C. (2017). The relationship between start-up motive and earnings over the course of the entrepreneur's business tenure. Journal of Evolutionary Economics, $1-23$.

William Y., \& Fiona T. (2006). Can businesses move beyond efficiency? The shift toward effectiveness and equity in the corporate sustainability debate Pages 402-415 Volume 15, Issue 6, DOI: $10.1002 / \mathrm{bse} .510$

\section{Copyrights}

Copyright for this article is retained by the author(s), with first publication rights granted to the journal. 